\title{
A Value Chain and Marketing of Iranian Cashmere
}

\author{
H. R. Ansari-Renani \\ Animal Science Research Institute \\ Karaj, Iran \\ (Received 09-01-2014; Reviewed 14-02-2014; Accepted 31-03-2014)
}

\begin{abstract}
Iran together with Afghanistan is the third largest producer and exporter of cashmere in the world, after China and Mongolia. This paper assesses the status of cashmere marketing of Iran in order to evaluate sustainability, and to identify some constraints limiting the productivity and compatibility. In August to December 2011 structured questionnaires and interviews were used to compile information regarding market chains cashmere industry of Iran. Information compiled revealed that nearly all the cashmere was marketed by direct buying in Iran. The principle centers for the gathering and rough sorting raw cashmere in Iran were Baft, Sirjan, Mashad, and Birjand. The principle cashmere-importing countries of Iranian cashmere were China, England, Belgium and Italy. The price for Iranian cashmere has showed large fluctuations in the last forty years: it increased from 25 dollars in 1972 to 110 dollars in 1988 and decreased to 65 dollars in 2006 and again increased to 110 dollars in 2012. Given the present status of production and marketing there seems to be substantial scope to improve the value addition of Iranian cashmere.
\end{abstract}

Key words: cashmere, production, marketing, export, value addition

\section{ABSTRAK}

Iran dan Afganistan merupakan negara penghasil dan eksportir kasmir terbesar ketiga di dunia, setelah Cina dan Mongolia. Penelitian ini menyampaikan kondisi pemasaran kasmir di Iran dengan tujuan untuk mengevaluasi sustainability, dan mengidentifikasi faktor yang menghambat produktivitasnya. Pengambilan data tentang informasi rantai pemasaran kasmir di Iran dilakukan mulai bulan Agustus-Desember 2011 melalui interview dengan menggunakan kuesioner terstruktur. Informasi yang diperoleh menunjukkan bahwa hampir semua kasmir dipasarkan secara langsung di Iran. Pusat pengumpulan dan penyortiran bahan mentah kasmir di Iran adalah di Baft, Sirjan, Mashad, dan Birjand, sedangkan negara importir utama kasmir Iran adalah China, Inggris, Belgia, dan Italia. Harga kasmir Iran sangat berfluktuasi selama 40 tahun terakhir: meningkat dari 25 USD pada tahun 1972 menjadi 110 USD pada tahun 1988, namun turun menjadi 65 USD pada tahun 2006 dan meningkat kembali menjadi 110 USD pada tahun 2012. Adanya data terbaru status produksi dan pemasaran kasmir merupakan peluang penting untuk meningkatkan nilai tambah dari kasmir Iran.

Kata kunci: kasmir, produksi, pemasaran, ekspor, nilai tambah

\section{INTRODUCTION}

Cashmere is the fine, undercoat fibre (down) produced by cashmere goats in some of the most arid parts of Central Asia, including China, Mongolia, Iran and Afghanistan. Annual production of cashmere is $<0.01 \%$ of the world textile market and its contribution to the annual global fiber tonnage is negligible. Iran together with Afghanistan is the third largest producer

*Corresponding author:

E-mail: ansarirenani@yahoo.com and exporter of cashmere in the world, after China and Mongolia (FAO, 2011).

Cashmere production and harvesting is difficult and labour intensive (Ansari-Renani et al., 2013) as the quantity produced is very limited, the price of this luxury fibre is high to very high and can be subject to wide fluctuations in the international markets leading to prices increasing or decreasing by $50 \%$ or more in a short period of time (Schneider, 2012). Being expensive, cashmere necessarily have a market which is limited to wealthy consumers who buy luxury goods not only for its intrinsic qualities of appearance, softness, warmth, handle and comfort but also simply because they are rare and exclusive. 
The world demand for cashmere is growing, for both fine and coarser cashmere, the latter due to introduction of relatively cheap $100 \%$ cashmere or cashmere blend garments. European high fashion houses continue to seek the best quality available and wish to access alternatives to China for supplies of fine cashmere, as China increasingly gains a monopoly over the world's production (Waldron et al., 2011).

Of the 24.6 million goats in Iran (FAO, 2012), 5 millions are cashmere producing and the remaining goats are meat and milk type (Ansari-Renani, 2012, AnsariRenani et al., 2012). 40\% of all goats are kept by nomads (Ashayer) in a habitat of about $59 \%$ of the total area of the country (Kamali et al., 2004,) Exact quantity of cashmere production and export of Iran is not known but it can be estimated that 5 million cashmere goats produce about 2000 tons of raw cashmere annually. This quantity of cashmere is exported either raw or processed.

Major producers of cashmere in Iran are nomadic pastoralists and they are distinguished by herd size, income levels, and grazing techniques (Ansari-Renani et al., 2013). About half of nomad households own 200-300 goats; with 23 and $30 \%$ of families owning less than 200 and more than 300 goats respectively (Ansari-Renani et al., 2012). Livestock is the largest non-land asset they own and predominates as a source of livelihood and supply of food. Nomadic pastoralist system is characterized by low population density, self-reliance on basic needs, displacement of livestock between grazing sites in different seasons and weak linkages to markets and public services. Rangeland is considered as the main source of grazing and depends on seasonal rainfall. In the previous decades these households have been able to operate at the margin only due to the implicit subsidiesfree public land and water and explicit subsidies-free restocking of goats after devastation of livestock in harsh winters and drought seasons.

The two main cashmere producing goats are Raeini and Birjandi in Kerman and South Korasan Provinces respectively. The Raeini breed is a cashmere producing goat with an average live weight of $35 \mathrm{~kg}$ for males and $30 \mathrm{~kg}$ for females produce on average $507 \mathrm{~g}$ of cashmere with 56.5 percent yield and 19.5 micrometer fiber diameter and a staple length of $54.2 \mathrm{~mm}$ (Ansari-Renani et al., 2012) which produce mainly white cashmere. Birjandi breed in South Khoransan Province is also a cashmere producing goat (Ansari-Renani, 2004) with a small body size, short legs, straight back, small face, plain horns and small beard. This breed of goat produces black color cashmere with $67.4 \%$ yield and 18.8 microns fiber diameter and a staple length of $4.06 \mathrm{~mm}$ (Ansari-Renani, 2004).

The quality of Iranian cashmere being long and highly curved (Ansari-Renani et al., 2012; McGregor, 2007) ranks third in price after China and Mongolia (FAO, 2011). At present no price differential is paid to the producers for fine cashmere, and the producers of cashmere are not aware of world market prices for different cashmere quality classes (Ansari-Renani et al., 2012). A major portion of cashmere is exported without any added value through processing. As a result of the marketing system, producers do not achieve good prices and have little incentive to produce better quality cashmere.

Raw cashmere export is one of the sources of foreign currency for Iran. Eastern Iran expanded its processing facilities to produce better quality cashmere and to become an integral part of the world cashmere industry. However, most of the cashmere is still sold either raw or dehaired to European and Chinese processors through exporters (Schneider, 2011). Limited information exists nationally and internationally on trading, processing and retailing of Iranian cashmere. This study intends to fill this gap by collecting primary source information from key actors and complimentary secondary data from both national and international sources.

\section{METHODS}

\section{Cashmere Producing Areas Included in the Study}

Kerman Province is a highland region with $<250$ $\mathrm{mm}$ annual rain and $85 \%$ of the nutrition of goats is based on range and $15 \%$ on forage and post harvest cereals produced in farms for fall and winter feeding. Summer is hot (up to $35{ }^{\circ} \mathrm{C}$ ) and dry and winter is moderate (up to $-8{ }^{\circ} \mathrm{C}$ ). Baft city (latitude $29^{\circ} 17^{\prime} \mathrm{N}$ and longitude $\left.56^{\circ} 36^{\prime} \mathrm{E}\right)$ is located in the south of Kerman Province, $2270 \mathrm{~m}$ above sea level.

South Khorasan Province is also a highland region with $<250 \mathrm{~mm}$ rain, $80 \%$ of the nutrition is based on range and $20 \%$ on forage and post-harvest cereals produced in farms for fall and winter feeding. Summer is hot (up to $41^{\circ} \mathrm{C}$ ) and dry and winter is cold (as low as $\left.-28^{\circ} \mathrm{C}\right)$.

\section{Survey Methodology}

In depth open interviews and group discussion was used for acquiring qualitative data (Klein et al., 2007). Interviews and discussions were conducted in Persian language from August to December 2011 mainly in the eastern regions with key industry actors in Iran: producers, buyers and processors of cashmere. Three different structured questionnaires for producers, buyers and processors were completed to compile information regarding quality and quantity of cashmere, selling season/month, factors important to make decision of cashmere price, means of transport, kind of payment, type of agreement with buyer/seller, market accessibility, type of sorting/storage, packaging, processing machines: scouring, garneting, dehairing, combing, challenges, education, training and customs.

Seven 2-3 day periods of fieldwork were conducted from August to September and October to November 2011 to interview 40 cashmere farmers in each of the Baft and Birjand regions in Kerman and South Khorasan Provinces respectively. Three 2-3 day periods of field work in December 2011 were also conducted to interview 15 middlemen in main marketing cities of Kerman, Sirjan, Birjand and Mashad. Another two 1 day periods of fieldwork were conducted in December 2011 to interview the owners of cashmere mills in Semnan and Mashad Provinces. 


\section{Information on Prices and Marketing Margins}

Price information along the value chain was obtained from the different sources (actors) along the value chain, and cross-checked with each other. Prices for raw cashmere were obtained from farmers, district, provincial and national level assemblers and the exporters, and margins were calculated accordingly. Export prices for raw and dehaired cashmere were obtained from processors and exporters. Wholesale and final garments were obtained from reviews of different websites. The volume of marketed cashmere and corresponding number of goats were mainly derived from available literature, national census and official statistics.

\section{RESULTS AND DISCUSSION}

\section{Cashmere Marketing}

Producers. A competitive advantage for the cashmere industry in East Iran was its access to raw cashmere, which was produced by low income nomad herders in Eastern Iran and bordering Afghanistan. There was a large seasonal variation of supply, demand, and price of cashmere. Cashmere harvesting and buying took place over a short spring period in nomadic areas. About $80 \%$ of cashmere was sold to dealers from April to June and $20 \%$ of the remaining was sold in July. While $62 \%$ of nomad farmers sold their cashmere in one period of time $22 \%, 11 \%$, and $5 \%$ of farmers sold their harvested cashmere at two, three and four different intervals, respectively.

All 40 goat owners sold the whole fibre, undehaired, containing both rough outer hair and the inner fine cashmere to local or travelling merchants or traders. The raw cashmere was unsorted and sold at lower prices than could be expected if the cashmere was sorted at source into quality classes. This raw fibre in Iran was generally known as Kork.

Results from previous studies indicated that 30\% of cashmere was lost during shedding season and if not harvested it would be wasted (Ansari-Renani et al., 2011). In contrast to the interviewed framers it was known that the goat owners in Khorasan Razavi Province of Iran comb their cashmere goats during shedding season at the beginning of spring.

Nomad cashmere producers did not received seasonal price information on cashmere through reliable and up to date sources. Results indicated that $41 \%$ and $32 \%$ of nomads receive scattered marketing information from traders and neighboring farms while $14 \%$ and $13 \%$ received their information from associations and markets respectively.

Producers market cashmere on 'eye-ball' basis: transactions are made on individual basis and agreements reached after one-to-one bargaining between buyers and sellers. The reason for 'eye-ball' marketing was the lack of infrastructure for measurements.

Nearly all cashmere was marketed by direct buying. There had been some changes in marketing from time to time and for various parts of the country, but in general no drastic changes from years ago. Perhaps the biggest change had been the general trade practice whereby most of the warehousing of cashmere was done near the source of supply. Another change had been the increase in direct buying by processors or manufacturers.

According to the interviewed cashmere producers (Figure 1), the local buyers collected cashmere and either sold to a merchant in town or store in their own facility. Most dealing of this kind was with farms having but limited number of goats.

The nomads stress the fact that life in the nomadic region had become very hard due to economic situation. Nomads noted that their livestock did not produce enough milk, cashmere and meat to sustain them throughout the year. Thus, the nomads had to consume a larger part of the yield of their capital (livestock) than they would otherwise had done. This could have dire consequences, since they constantly were under threat of losing part of their herds due to environmental factors, and smaller herd size made it more difficult to survive a disaster by reoccupying herd size during good years. Nomadic pastoralists were declining in number and resort to all means of professions which was exacerbated due to efforts of the governments to sedentarize them and due to severe environmental conditions such as droughts which force the nomads to search for wages in urban settings.

Middlemen. The more important agencies involved in getting the cashmere from the producer to the manufacturers were: the country buyer, the country assembler or cashmere-warehouse handler or dealer or combination, local cashmere pools, the commission merchant, and the broker.

Many local dealers or purchasers of small lots of cashmere might be junk dealers or feed-store operators. Many of these dealers specialized in not only cashmere but other products of the region such as furs, hides, pelts, iron, poultry, or possibly livestock. Usually the cashmere was sold ungraded, at a flat price. However, if some preparations had been done on the fleeces, they might be roughly sorted. Cashmere was loosely packed by middlemen in tall narrow polyester bags ( $90 \times 36 \times 30$ $\mathrm{cm})$, weighing about $100-150 \mathrm{~kg}$ per bag.

Cashmere pools had operated for years and were becoming more numerous in the Eastern cashmere producing provinces. These pools were usually made up of many growers' clips in a nearby locality that pool their cashmere in one central location and had buyers come and make a price offer. Sometimes the cashmere might be sorted, but more often they were not.

In nomadic areas, cashmere buyer might be a local man living in the range all year around, or he might be a man sent directly from the country buyer. Some large consumers of cashmere during the last several years had set up permanent buying organizations at central locations in the nomadic areas of eastern cashmere-growing sections. Thus, the buyers were closer to the source of cashmere and the effect of saving here and also through direct shipments to mills. Local buyers generally work on commission; which was based on the amount of cashmere purchased, whereas some buyers were normally paid a salary and his traveling expenses. Some eastern cashmere middlemen had purchasing orders 


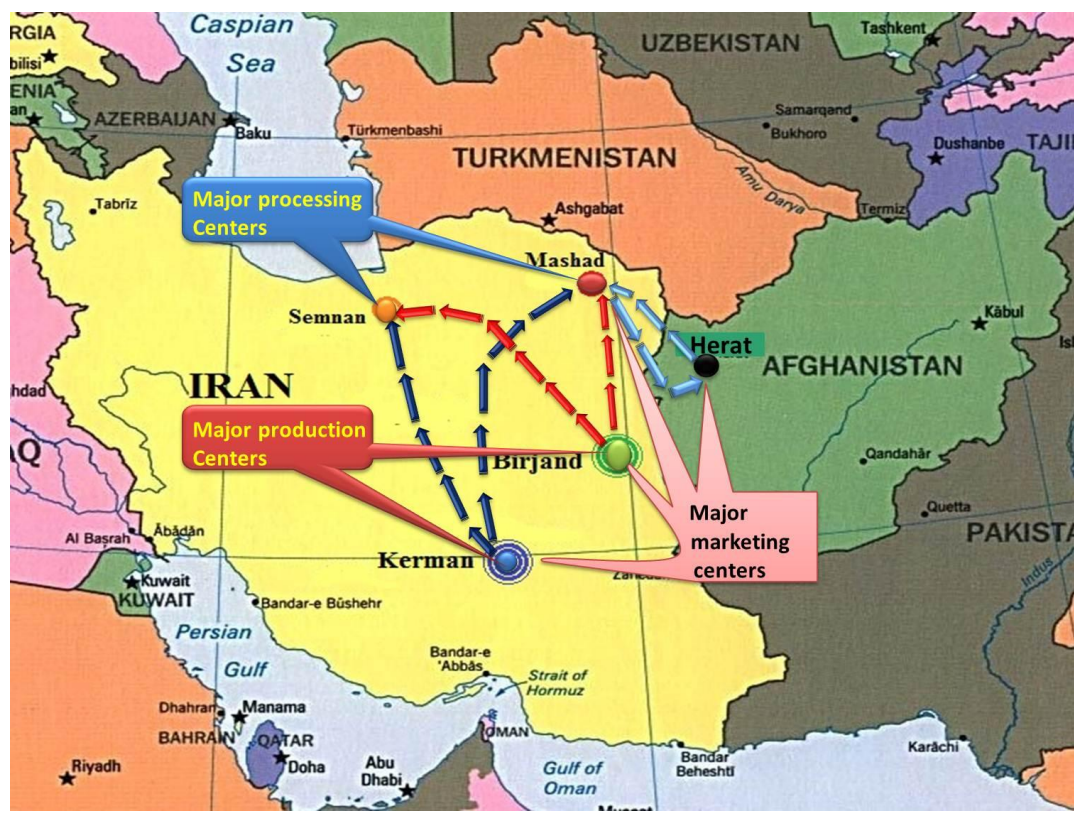

Figure 1. Major production, marketing and processing centers of Iranian cashmere. Dark blue and red arrows indicate cashmere is being transported from major cashmere production centers to Mashad and Semnan cashmere processing plants, while the light blue arrow shows cashmere from Afghanistan is being transported and processed in Mashad scouring and dehairing facilities.

from different merchants or mills for specified quantities of various types of cashmere. This was done especially by larger mills, who desire to purchase in advance cashmere suitable for sale requirements, and in such cases the buyer works on a commission.

Cashmere producers in the nomadic areas sold unsorted raw cashmere at lower prices than could be expected if the cashmere was sorted at source into quality classes. Nomad cashmere producers did not receive seasonal price information on cashmere through reliable and up to date sources. Results indicated that $41 \%$ and $32 \%$ of nomads receive scattered marketing information from traders and neighboring farms while $14 \%$ and $13 \%$ received their information from associations and markets respectively.

After harvesting, cashmere was bought directly from the herders by middlemen and the fibre was stored in warehouses according to colour and fineness. A basic problem of operators of cashmere warehouses in some years especially during drought was to obtain adequate volumes of cashmere for efficient handling. This involved consideration of the sources and availability of potential supplies, the competition of others and transportation facilities and costs. With adequate volumes of cashmere available, other problems included securing adequate protection from losses by fire and other hazards at reasonable costs, obtaining and maintaining suitable facilities and equipment for rendering the essential warehouse and related services efficiently, securing adequate information concerning the quality and commercial value of the cashmere handled, and maintain suitable contacts with market outlets for disposing of the qualities of cashmere handled.

From gathering centres raw sorted cashmere was also sent in bales by trucks or by train to Bandar Abbas and Khoramshahr, the main Iranian exporting ports in the Persian Gulf. From these ports baled raw cashmere was shipped to Italy, Belgium, and England. However about $1 / 3$ of raw Iranian cashmere stock went to Semnan and Mashad for processing. Processed cashmere also found its way to the same Persian Gulf ports to be exported to England and Italy.

The manufacturer or country buyer sent his representative through the small towns to dealer or to local warehouses to buy the cashmere. The cashmere purchased might then be shipped to the main trading centres, such as Baft, Sirjan, Mashad, and Birjand (Figure $1)$.

These centres had long been considered the leading market in Iran. Since 1950s the market established itself near the production areas, with more shipments going directly to mills. Mashad continued as the main centre of cashmere industry as most of the large manufacturers, exporters, dealers and selling agents and warehouse dealers were located there. Khorasan Razavi Province with Mashad city as its centre having common border with Afghanistan played an important role in processing and marketing of Afghan cashmere industry. Figure 2 illustrates the main market channels of Iranian cashmere.

Cashmere mills and export market. The local mills in Mashad and Semnan that were included in the study scour and dehair about $30 \%$ of the locally produced cashmere and $29 \%$ of Afghanistan clip. Figures 1 and 2 illustrate the major processing centres of Iranian cashmere.

Almost all Iranian processed dehaired cashmere was exported to European countries for making tops and garments. Distribution pathway of raw cashmere shipments from Iran to the major importing countries 
are presented in Figure 3. The figure shows that cashmere was exported to China and European countries. World trade of Iranian cashmere was accounted for principle cashmere-importing countries of China, England, Belgium and Italy.

China was not only a heavy producer but also a major importer of Iranian raw cashmere. While China was much the larger exporter of finished products, it was also the largest importer of raw and processed cashmere. While nearly all cashmere was until the early 1990s sold to established processors in Europe and Japan, Chinese cashmere processors now processed most of the world's cashmere products (Jiang, 2005; China Wool Textile Association, 2009). Due to uncompetitive labour and other input costs, European countries that traditionally processed raw or partially processed cashmere-mainly Italy, Belgium and UK-have reduced their cashmere processing facilities in Europe. European mills and traders were simply unable to buy enough cashmere at a price that would allow them viably process it, which effectively strangles their operations. These European and some USA firms had since developed joint ventures with Chinese and Mongolian cashmere processors. Europe still remain the world's second largest processing region,

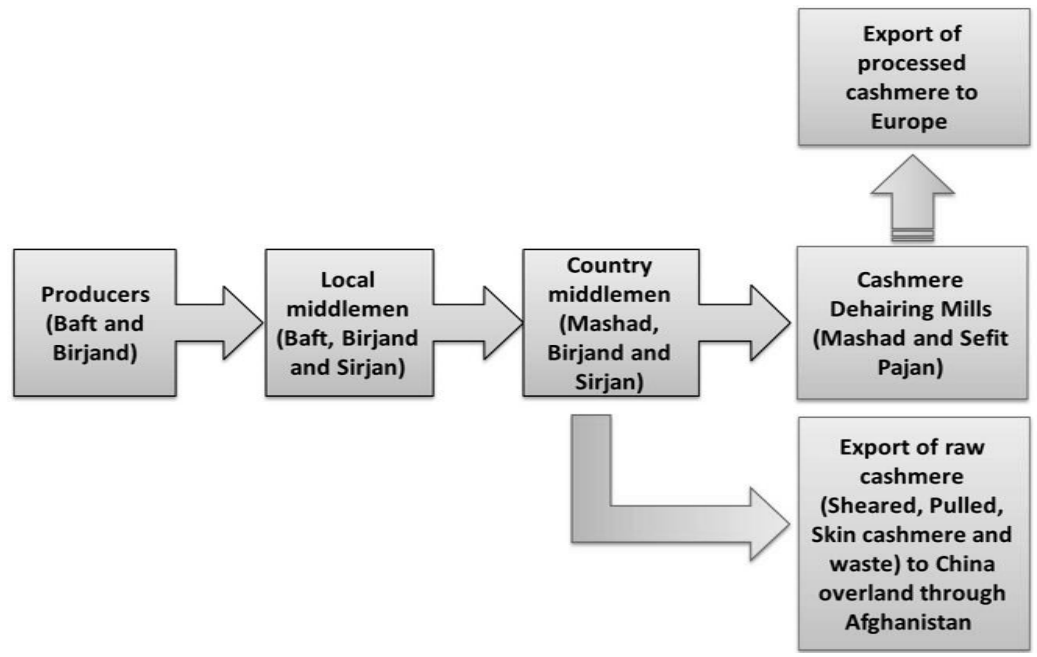

Figure 2. The principle channels for the gathering and rough sorting raw cashmere in Iran

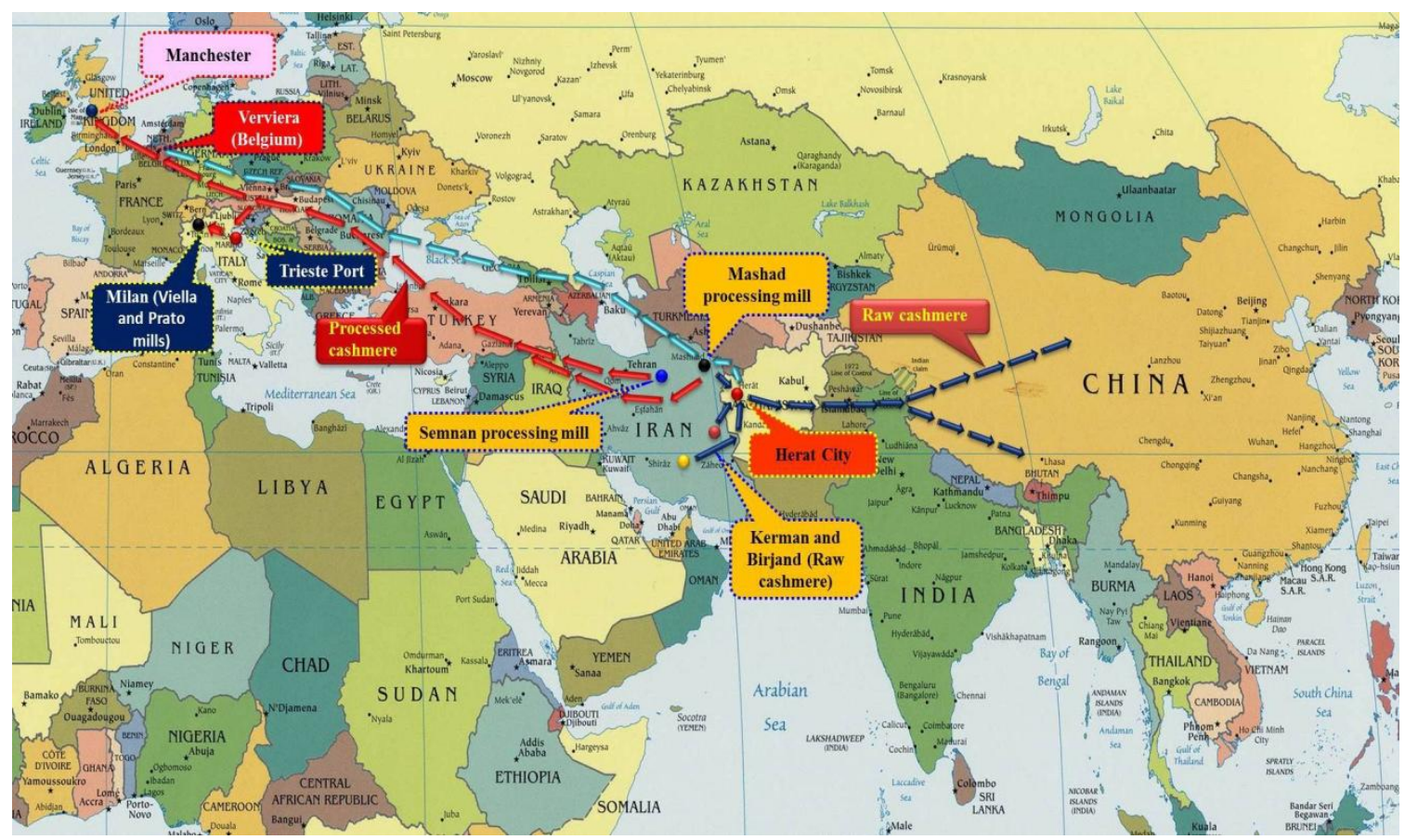

Figure 3. Distribution pathway of raw cashmere shipments from Iran to the major importing countries. Light blue and red arrows indicate cashmere is being exported from major cashmere processing centers of Mashad and Semnan in Iran to Machester in England, Milan in Italy and Verviers in Belgium respectively, while dark blue line indicated raw Iranian cashmere is exported to China. 
accounting for $13 \%$ of world exports, primarily for the intra-EU trade (Waldron et al., 2011).

China also imported significant volumes of cashmere in various forms. Access to imported cashmere provided another important source of competitive advantage to Chinese processors, especially as the trade partners were located in the relatively nearby regions of Pakistan, Afghanistan, and especially Mongolia.

The majority of the world's cashmere, regardless of country of origin, now made its way to China for some or all of its processing. The largest exception to this was Mongolia which had a well-developed cashmere production and processing system. Reports in the Wool Record suggested that China in 2011 had a 100\% over capacity for cashmere processing. This was likely to result in the closure of less efficient cashmere processors in China in future (Waldron et al., 2011).

The ability of Chinese -and especially Western Chinese- mills to access cashmere inputs at lower costs than their competitors, acted as a major source of competitive advantage. As was the case for other agroprocessing sectors, "raw material" (i.e. cashmere) inputs make up the bulk of all costs for processors (Brown et al., 2005). In a bid to support continuity of supply to processors and the incomes of cashmere goat processors and to develop the industry as a whole, China had taken measures to develop the cashmere production and marketing sectors as part of broader industry upgrading process. Mongolia also had considerable overcapacity in processing (Lecraw et al., 2005).

Afghan cashmere had traditionally been exported to Iran for early-stage processing, and then exported for final processing (de Weijer, 2007). However, with decreased purchases from Europe because of the global financial crisis, Chinese buyers had become very active in Afghanistan (Cashmere Fibres International, 2009).
Iranian traders played an important role in the export of Afghanistan raw and dehaired cashmere to Verviers, which might explain why most of the cashmere production and trading was still taking place in the northwest west of Afghanistan (Altai Consulting, 2005) close to Mashad city in Iran (Figure 1). Cashmere from Afghanistan was being processed in Mashad scouring and dehairing facilities and then transported to Europe through Iran. Iranian processors had established relations with certain Herati exporters in Afghanistan, who supply these dehairing facilities.

\section{Cashmere Prices and Valued Addition along the Marketing Chain}

Increased demand from Chinese processors, along with supply-side constraints has increased international cashmere prices. Figure 4 shows that between 2002 and 2010 annual average prices increased by $10 \%$ in China and $11 \%$ in Mongolia and Iran. These price signals triggered an expansion of the Mongolian goat heard at an annual average rate of $10 \%$ over the period, to reach 20 million head (the vast majority of which are cashmere goats). While China had by far the worlds largest goat flock (of 152 million head), statistics for China as a whole did not distinguish between cashmere and meat goats. While cashmere goat numbers had plateaued in pastoral and semi-pastoral counties, cashmere production in China increased at an annual average rate of $9.6 \%$ between 2000 and 2008 to reach 10000 tonnes (Schneider, 2012). Goat population of Iran increased by $5 \%$ over the same period to 25 million heads which rank $5^{\text {th }}$ in the world. Pastoral and semi-pastoral regions of Iran produced almost 75\% of all Iran's cashmere. Only one-fifth of Iranian goat population was cashmere producing, however based on household surveys and interviews

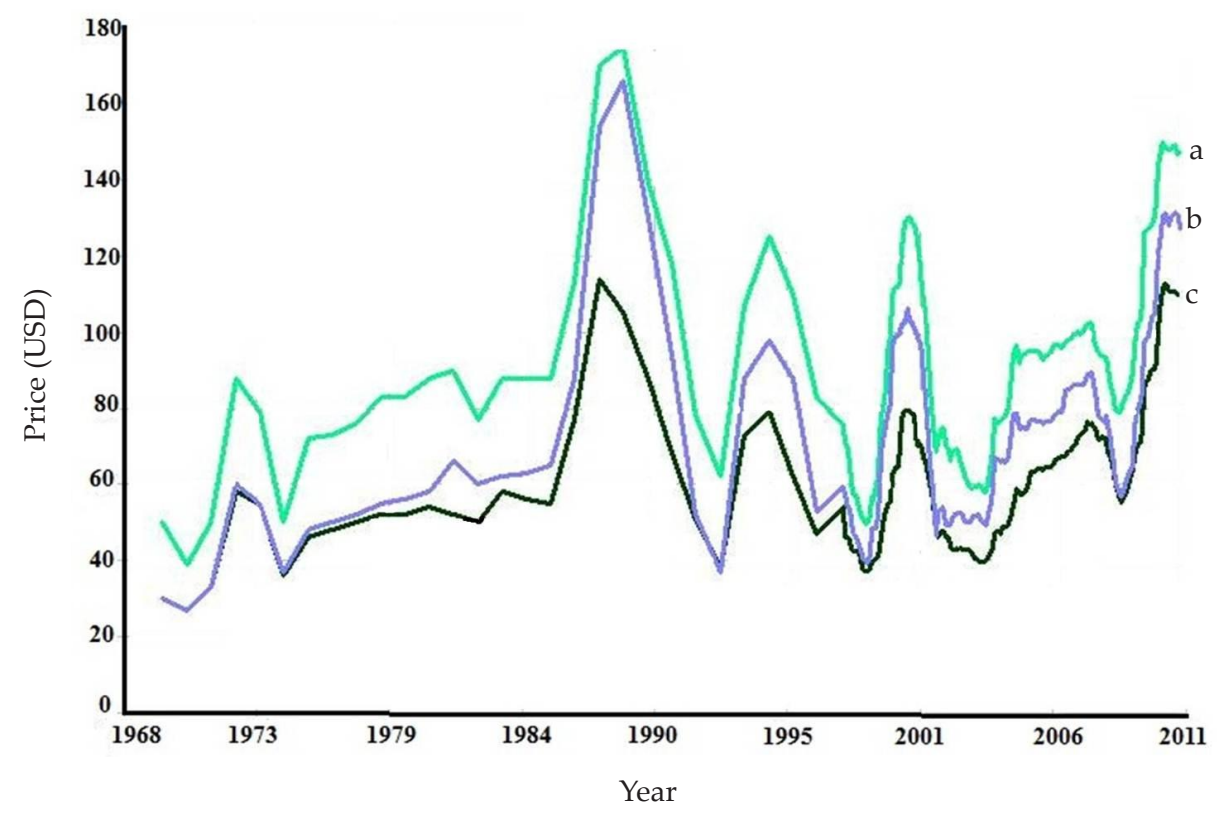

Figure 4. Cashmere price of China (a), Mongolia (b), and Iran (c) over time. Chinese cashmere is sold at a higher prices than Mongolian (second highest) and Iranian cashmere (Schneider, 2012). 
conducted (Ansari-Renani, unpublished), the modeling indicated that households had clear incentives to switch from the production of native goats to cashmere goats and, of the cashmere goat breed activities available, maximized profits by selecting Raein and Birjandi cashmere breed of goats over hairy type (scrub) goats with a population of more than 18 million heads. This population of hairy goats had an undercoat of downy fibre that was classed as "cashmere". While only a very small quantity of this down was produced per animal, it could be worthwhile for farmers or traders to comb or fellmonger the down from skins, especially when prices were high. This cashmere could be used to produce low value products and for blending to produce "cashmere" products. If no price-grade differentials were paid for the cashmere- as was the case under the current Iranian marketing system-then due to their higher cashmere yields, Raeini cashmere breeds of goats were 15\% more profitable than hairy goats.

The over-stocking of livestock, especially goats, had led to the degradation of grasslands (Brown et al., 2008) which imposed strict limits on further flock expansion in China and Iran. To address grassland degradation, these countries had applied grazing bans and restriction.

The Afghan cashmere was traditionally transported to Belgium through Iran (Figure 3). Verviers, in Belgium, used to be the main market centre for cashmere, as it was suited in the core of the textile centre in Europe. Nowadays, the role of Verviers as the main market place has diminished, but for Afghan cashmere Verviers is still a major destination through Iran.

There were many cashmere types available as can be seen in Table 1 which however was not inclusive as it did not show figures for low volume cashmere types such as Australian cashmere goats. The price of the cashmere types available in Table 1 would vary both annually and monthly. The Wool Record (World Textile

Table 1. Some dehaired cashmere types, available internationally, defined by country of origin, colour, length and mean fibre diameter

\begin{tabular}{llcc}
\hline \multicolumn{1}{c}{ Origin } & \multicolumn{1}{c}{ Colour } & $\begin{array}{c}\text { Length } \\
(\mathrm{mm})\end{array}$ & $\begin{array}{c}\text { Diameter } \\
(\mu \mathrm{m})\end{array}$ \\
\hline China & White & 38 & 15.3 \\
& White & $34-36$ & 15.3 \\
\multirow{4}{*}{ Iran } & White & 32 & 15.3 \\
& Brown & $34-36$ & \\
Afghanistan & White & 38 & \\
& Fawn & 36 & \\
& Dark & 36 & \\
& Light grey & 36 & \\
& Light natural & 36 & \\
& Dark Afghan & 36 & \\
& Red & 38 & 16.2 \\
& Light grey & 38 & 16.4 \\
& Brown & $38-40$ & 16.4 \\
\hline
\end{tabular}

Source: Cashmere Fibres International, UK (2009).
Publication Ltd., 2010) listed two types of cashmere according to length (32 and $38 \mathrm{~mm}$ ) in the monthly price round up and could be used as a general indicator of market movement as could the price indicator found in The Schneider Group.

For example, Iranian and Afghan cashmeres had diameters 2-3 $\mu \mathrm{m}$ greater than Chinese cashmere and were $40 \%-50 \%$ cheaper (Schneider, 2011). Colour was also an important factor, white being the most valuable because it could be used not only as it was but could be dyed to the pastel shades which were often required for knitwear. Brown was the least valuable colour because it could only be dyed to dark shades.

Cashmere price was very dependent upon fashion, as reflected in large fluctuations in price. Chinese cashmere price increased from 80 dollars in 1972 to 180 dollars in 1988 and decreased to 95 dollars in 2006 and to 150 dollars in 2011 respectively (Schneider, 2012) (Figure 4). Iranian cashmere price also had large fluctuations and increased from 60 dollars in 1972 to 110 dollars in 1988 and decreased to 65 dollars in 2006 and again increased to 110 dollars in 2011(Schneider, 2012).

As a result of increase in prices, there has been a drop in demand for $100 \%$ cashmere products in USA, Europe and Japan. Some large retailers had moved to blended product and/or cut back on cashmere buys. While that had taken place, Chinese consumer market was more than making up for the loss in export business for Chinese mills. There were many reasons for optimism about the international market. Demand for luxury goods was growing worldwide and was well balanced globally. Demand for finished cashmere articles was high income-elastic, and trade in cashmere and cashmere products was likely to continue growing (World Bank, 2010).

The other factor that was contributing to prices remaining firm and continues to increase had to do with supply. There was a definite shortage of supply problem in every producing area. In fact, every cashmere producing area, big or small was experiencing the same problem. There were also other macro government issues related to profession and population of nomads.

Higher export earnings from cashmere would help to boost the income of a large number of Iranian cashmere herders, and though we did not have information about the relative position of herder households in the income distribution, it was clear that many of them represent the poorest segments of Iranian society. There were ambiguities, however, about the sustainability of cashmere production as a livelihood for nomad and small holder households.

Value addition took place at different stages of the production and market chain. Most of the power within the value chain resides with the private-owned processing firm and retailer; herders were the largest group of actors but perhaps the least powerful. Lack of market information made herders vulnerable to exploitation by processors and traders, and without price differentials between high-quality cashmere and other grades, herders lack incentives to invest in improving their herds. 
Currently Iran was engaged with the cashmere production, harvesting, scouring, dehairing, carding and combing; the low to medium added cashmere value activities at the downward section of the chain. Figure 5 shows cashmere value chain of harvested at farmer, assembly and exporter levels. Despite 50\% unavoidable loss from washing and removing the outer guard hair from cashmere, the value was doubled by weight after this stage. Thus after scouring and dehairing $1 \mathrm{~kg}$ of raw greasy cashmere was transformed to four times its initial value. Major bur and grease seed contaminants of cashmere resulted in serious price penalties and so did the guard hair levels. Any undesirable contaminant, that would either affected the quality of the final product or would have to be removed, reduced the economic value of the cashmere. Burrs or excessive vegetable matter in the fleece also had to be removed. Urine and certain types of soil and vegetable matter contained substances which stain cashmere permanently. These affected the dyeing and value of the cashmere and the quality of the final product. Precautions must be taken to limit such stains, particularly urine stains.

Value added to cashmere in the several stages of processing mean that the final price for clean, dehaired and spun cashmere can be up to four times the raw greasy price received by producers. Value added along the different stages of the value chain is shown in Figure 6. This figure represents the transformation of price paid by local dealers per $\mathrm{kg}$ of raw cashmere to farmers to international market price of final product such as garments. Production of cashmere in Iran took place in selected provinces. At the lowest section of the value addition chain considerable potential existed to expand production of cashmere to goat farms in other provinces.

Such expansions should be done with care over time, as 'quick fixes' such as crossing with very high producing exotic goats tend to decrease fiber diameter

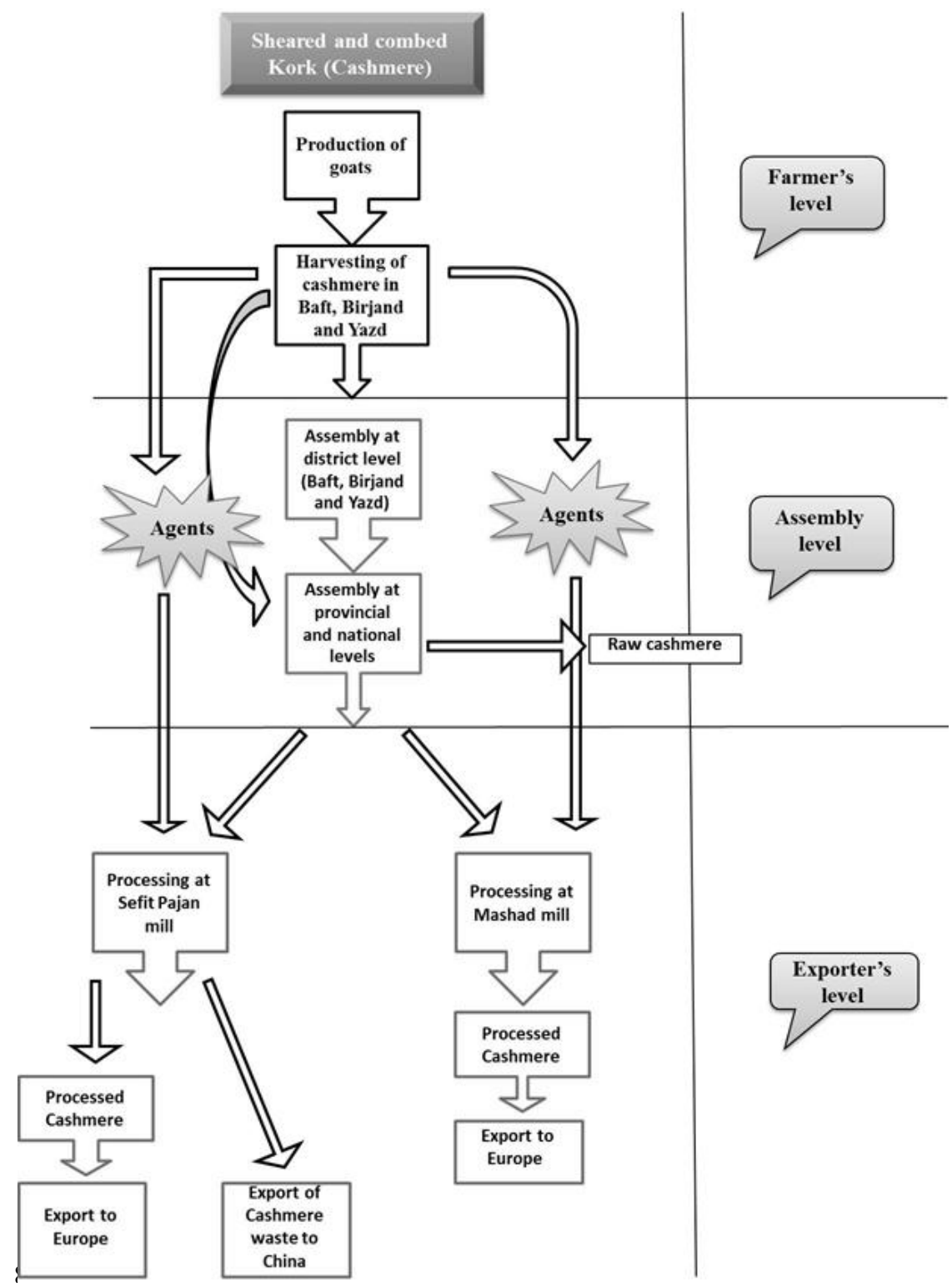

Figure 5. Market channels of harvested cashmere in Iran. Some raw cashmere on assembly level is exported to China. 


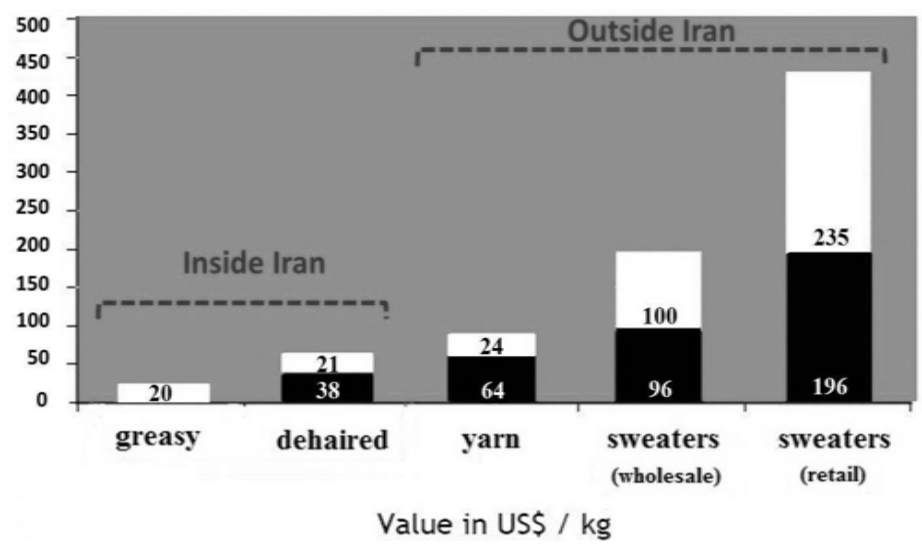

Figure 6. Cashmere value added chain within Iran (Adapted from Frank de Weijer, 2008); $\square=$ production cost, $\square=$ value added.

rapidly by reducing staple length and fiber curvature creating short, flat fiber. The way to restore the quality of Iranian cashmere was through herd selection and superior genetics. There was scope within the national herd to increase fiber yield without reducing fiber quality and thus increasing financial returns to farmers.

A producer training program on combing cashmere would add the commercial value of their cashmere. Highest yields came from the cashmere that were combed and not shorn. Commercially recoverable cashmere yields were higher from combed rather than shorn fleeces, making combed cashmere more attractive to textile processors. Very low yielding fleeces needed extra dehairing and have a higher residue of coarse fibres left after dehairing. The extra processing also tended to cause more fibre breakage, leading to lower final product prices and added commercial value as a result of shorter fibre length and hence lower yarn quality.

\section{CONCLUSION}

Nomad farmers as individuals sell their cashmere at farm with little knowledge of market demand and little ability to influence market outcomes. Poor marketing infrastructure, lack of access to formal credit sources, poor roads and exorbitant transport fees, lack of standardization and grading and low purchasing power of buyers are major constraints affecting the efficiency of cashmere market.

\section{ACKNOWLEDGEMENT}

Gratitude is given to International Fund for Agricultural Development (IFAD) for funding this study. Gratitude is extended to International Centre for Agricultural Research in the Dry Areas (ICARDA), Iranian Animal Science Research Institute, Agriculture and Natural Resources Center of Kerman Province and ICARDA office in Tehran for the support of this project. Special gratitude is also given to all the cashmere producers, dealers, traders, processors and policy makers in different provinces who shared and contributed their knowledge and information with the authors.

\section{REFERENCES}

Alti Consulting Ltd. 2005. Market Sector Association - SME development, Chapter V, "Cashmere". Altai Consulting for UNDP Kabul. Afghanistan.

World Textile Publications Ltd. 2010. Specialty fibres. Wool Record Weekly Market Report, February $4^{\text {th }}$. World Textile Publications Ltd., Bradford, UK.

Ansari-Renani, H. R. 2004. Fibre and follicle characteristics of Iranian cashmere and mohair producing goats. First Animal and Fisheries Congress. Tehran University, Iran. Pp. 867-871.

Ansari-Renani, H. R. 2012. Cashmere quality of Iranian goat breeds. Med. Pet. 36:1-5.

Ansari-Renani, H. R., Z. Ebadi, S. Moradi, H. R. Baghershah, M. Y. Ansari-Renani, \& S. H. Ameli. 2011. Determination of hair follicle characteristics, density and activity of Iranian cashmere goat breeds. Small Rumin. Res. 95:128-132.

Ansari-Renani, H. R., J. P. Mueller, B. Rischkowsky, S. M. Seyed Momen, O. Alipour, M. Ehsani, \& S. Moradi. 2012. Cashmere quality of Raeini goats kept by nomads in Iran. Small Rumin. Res. 104: 10-16.

Ansari-Renani, H. R., J. P. Mueller, B. Rischkowsky, S. M. Seyed Momen, M. Ehsani, \& S. Moradi. 2013. Observations on the efficiency of using different cashmere combs. Small Rumin. Res. 114:220-224.

Brown, C. G., S. A. Waldron, \& J. W. Longworth. 2005. Modernizing China's Industries: Lessons from Wool and Wool Textiles. Edwards Elgar Publishing, Cheltenham.

Brown, C. G., S. A. Waldron, \& J. W. Longworth. 2008. Sustainable Development in Western China: Managing People, Livestock and Grasslands in Pastoral Areas. Edwards Elgar Publishing, Cheltenham.

Cashmere Fibres International. 2009. Market Report-November 2009. http://www.cashfibres.co.uk/market-report-nov2009

China Wool Textile Association. 2009. Yangrong hangye qingkuang ji fazhan jianyi (The Situation and Development Recommendations for the Cashmere Industry).

De Weijer, F. 2008. Cashmere Value Chain Analysis-Afghanistan. USAD/Accelerating Sustainable Agriculture Program. http://afghanag.ucdavis.edu/other-topic/markets/ marketing-reports/Rep_Cashmere_Value_Chain_USAID. pdf.

FAO. 2011. FAOSTAT. www.faostat.fao.org

FAO. 2012. FAOSTAT. www.faostat.fao.org

Jiang, J. J. 2005. Cashmere, environment need better balancing. China Daily Journal. 
Kamali, M. A., A. A. Gharadaghi, M. R. Kianzad, H. R. Ansari-Renani, M. Zahedifar, S. Amirinia, J. Tavakolian, S. Ghorbani, \& S. Nomi. 2004. IRAN'S Country Report on Farm Animal Genetic Resources. Animal Science Research Institute. Karaj, Iran.

Klein, E. E., T. Tellesfsen, \& P. J. Herskovitz. 2007. The use of group support systems in focus groups; information technology meets qualitative research. Comput. Hum. Behav. 23:2113-2132.

Lecraw, D. J., P. Eddleston, \& A. McMahon. 2005. A Value Chain Analysis of the Mongolian Cashmere Industry. Mongolia Economic Policy Reform and Competitiveness Project (EPRC). Ulaanbaatar, Mongolia.
McGregor, B. A. 2007. Cashmere fiber crimp, crimp form and fiber curvature. International Journal of Sheep and Wool Science 55:106-129.

Schneider, G. S. 2011. Market Indicators. http://www.gschneider.com/indicators/index.php

Schneider, G. S. 2012. Market Indicators. http://www.gschneider.com/indicators/index.php

Waldron, S., C. Brown, \& A. Komarek. 2011. The sinofication of global value chains, rural development and cashmere. Proceeding of $10^{\text {th }}$ European Conference on Agriculture and Rural Development in China. Aarhus, 8-10 April 2011.

World Bank. 2010. Trends in the Global Cashmere Market. http://www.worldbank.org/eaptrade. 